\title{
Socio-Economic And Divorce in Aceh Province
}

\author{
${ }^{1}$ AFZAL, ${ }^{2}$ ABD JAMAL, ${ }^{3}$ MUHAMMAD NASIR \\ 1,2,3 Faculty of Economics and Business, Syiah Kuala University, Indonesia \\ Email: 1afzal1993@mhs.unsyiah.ac.id; 2abdjamal@unsyiah.ac.id; ${ }^{3}$ nasirmsi@unsyiah.ac.id
}

\begin{abstract}
Socio-economic factors are always the benchmark of domestic life. There is an assumption that a household disharmony is caused by economic issues referred to as the highest number of divorce cases registered at Mahkamah Shari'a (Shari's Court) of Aceh. This research is very important since Aceh is a special region in terms of religion and culture so that the number of divorces would not be this much and it is hoped that the government will issue a regulation that can reduce the number of divorces. The research data are obtained from BPS (the Central Bureau of Statistics) of Aceh Province and the Sharia Court of Aceh which then analyzed using descriptive quantitative methods. The results indicate that recur of friction (in a household) is the major cause of divorce in Aceh followed by the economic factor and domestic violence. The level of individuals' education shows a significant influence on divorce along with the age when they first married, but children variable affected insignificantly. However, not all research in the same field has the same results as this study.
\end{abstract}

Keywords: divorce, sharia court, socio-economic

\section{Introduction}

Aceh is the westernmost province in Indonesia. It is located on the northern tip of Sumatra Island. Aceh is bordered by the Indian Ocean in the west, by the Bay of Bengal in the north, the Malacca Strait in the east, and North Sumatra in the southeast and south.

Aceh's population reaches 5.19 million people (BPS Aceh, 2017) that spread across 23 regencies/cities. Aceh is known as a starting point for the spread of Islam in Indonesia and Southeast Asia. At the beginning of the 17th century, the Sultanate of Aceh was the strongest and most advanced nation in the Malacca Strait. Until now, the people of Aceh still adhere to Islamic rules (Sharia), proven by the implementation of government and social order in accordance with the Sharia.

Aceh is a special area in terms of education, culture, and religion. The people of Aceh are known to be obedient and have a strong faith in religion (religious), upholding tradition and culture, and valuing the family as an important institution in society. With such a community background, divorce cases in Aceh should have been able to reduce to a low point. But the fact said otherwise and shows that the divorce rate in Aceh in recent years has continued to increase.

This is a very serious problem since the cultural and customary background of Aceh has specific rules, especially regarding marriages so that it will be difficult for a couple to get a divorce. However, based on data from the Aceh Shari'a Court, there are more and more divorce cases from year to year. Therefore, the authors are interested in conducting research on the causes of divorce that rife in Aceh. This is in accordance with data from Aceh Shari'a court stating that the number of divorces in Aceh in 2016 was 5,037 cases and increased to 5,399 in 2017. (Mahkamah Syar'iyah Aceh, 2017).

According to article 38 of Law Number 1 of 1974 on marriage, divorce is the release of marital status among man and woman as husband and wife which takes place before the court, for the non-muslim namely District Court and the Religious Court for the Muslim. While, according to the Code of Civil Law in article 207, divorce is the abolition of marriage by the judge's decision based on the demand

Received: 2019-08-18, Revised: 2019-10-21, Accepted: 2019-12-23 
of one party in the marriage based on the reasons stated in the Act.

According to Subekti (1985: 23), divorce is the abolition of marriage by a judge's ruling or the demands of one of the parties to the marriage. Islam has provided an explanation and definition that divorce, according to fiqh experts, is called talak or furqoh. Divorce is taken from the word Itlak, meaning to let go, or leave. Whereas in terms of syara', divorce is to break the bonds of marriage or the breakdown of marital relations.

The economic problem is one of the factors that frequently become the background of family problems and other problems. Likewise, most divorce cases have backgrounds of economic factors. Therefore, the economic factor is often regarded as the root of family problems that lead to conflict and friction which ultimately ends in divorce as shown in the research below. Rais, I. (2014) found the main factors that caused the divorce were disharmony, husbands failed to fulfill their obligations (including economic needs), persecution/violence, moral crises, financial difficulties, and unhealthy polygamy.

Thalib \& Lestari (2017) stated that divorce is influenced by several factors including women's awareness of their rights in the household, economic factors in which husband cannot meet the needs of his family due to minimal/less income, and poor husbands or husbands who do not have jobs. The next cause is domestic violence, infidelity, and third-party negative interference.

Matondang (2014) stated that the factors underlying divorce in Harapan village were marriage at a young age, economy, not having children, and husband often being abusive. Kabalmay (2015) stated that there were seven reasons for divorce in the Ambon Religious Court, namely unhealthy polygamy, moral crisis, forced marriage, economy, irresponsibility, persecution, and inharmonious relationship. In this connection, the lack of harmony between husband and wife is the most common reason in divorce cases that are heard by the Ambon Religious Court.

Cavapozzi et al. (2019) show that welfare variations negatively affect men and women and the welfare of men and women after a divorce is significantly higher than in previous years. Zuzana \& Kreidl (2018) found that divorced or separated grandparents tend to have a lower probability of providing better and intensive care for their grandchildren than married grandparents. The effect of divorce on intensive grandparental childcare seems to follow the opposite trend: it becomes stronger (i.e. more negative) when divorce becomes more common in society.

Tamborini et al. (2015) have investigated divorce as a turning point for women's earnings trajectories and whether those patterns have changed over recent decades. They use a unique data set that links retrospective family history data from the Survey of Income and Program Participation to longitudinal earnings records from the Social Security Administration. We find that women who divorced experienced long-lasting earnings increases, particularly among those who did not remarry. The increases in earnings levels are comparatively similar for those divorced at different times; however, percentage increases are significantly smaller for women experiencing divorce in more recent (19901994) relative to earlier (1970-1974) years.

However, not all divorce cases are influenced by economic factors, but rather by several other social factors such as disharmony in the household, abuse, child marriage, and the presence of a third person (Mahkamah Syar'iyah Aceh, 2017). Based on a simple understanding, education can be interpreted as a human effort to grow and develop their potential both physical and spiritual according to values that exist in society and culture (Ihsan, 2008: 1-2).

According to Widyastuti (2009: 395), a woman as a wife doesn't remain silent and doesn't want to be mistreated by a man, thus, the woman uses their rights by filing for divorce in court. Soekanto, S. (2007) States that a social status is a place where a person, in general, is in a relationship with other people in his social environment, prestige, rights and obligations. While socioeconomic status means the position of an individual and family-based on economic elements. Divorce creates certain negative effects on family members, especially for adolescents, such as aggressive behavior, depression, less positive interactions caused by a conflict with parents or lack of supervision by their parents (Rodgers \& Rose, 2002).

As it is regulated in Presidential instruction No. 1 of 1991 concerning the compilation of the Islamic law, there are three consequences of a break up of marriage due to divorce, namely child custody, joint property distribution, and Mut'ah (ex-husband gives things/money to his ex-wife). 


\section{Research Methodology}

This research is conducted in Aceh and focused on household socio-economic factors. The researchers study the 2017 data with variables such as education level, have/have not children and age of first marriage, recur of friction, economic, and domestic violence as independent variables; for the dependent variables, we use the divorced variable. We collect the secondary data from BPS Aceh and the Sharia Court of Aceh.

This research uses a descriptive analysis method with a quantitative approach. Sugiyono (2011: 207) explained that descriptive research is research that seeks to describe a phenomenon and events or current events where researchers try to photograph events that are the center of attention and then describe them as they are. Whereas, what is meant by a quantitative approach is the approach used in research by measuring the indicators of research variables in order to obtain a picture between those variables. The use of this quantitative descriptive method is harmonized with the research variables which focus on actual problems and phenomena that are happening at the present time with the results of the research in the form of meaningful numbers.

The purpose of descriptive research with the quantitative approach is to explain a situation that would be examined through the support of library studies so that it further strengthens the analysis of researchers in making a conclusion. The results of the study were obtained from the results of the calculation of research variables indicators then presented in writing by the author.

The type of data used in this study is secondary data. The data source in this study came from two institutions namely BPS/ Statistics of Aceh Province that provided 2017 Socio-Economic Survey Data (SUSENAS) with three variables namely educational level, have/have not children and age at first marriage; and the Shari'a Court of Aceh Province that provided data of variables of continuous/ongoing disputes, economy, and domestic violence.

\section{Results and Discussion}

\section{Analyzing the Level of Divorce in Aceh}

According to Act No. 1 of 1974, marriage is an inner and outer bond among men and women as husband and wife in the form of happiness and eternal family before God. Although marriage should be the strongest bond among men and women, sometimes it has a weakness that leads to friction and could end in divorce. To avoid that, the couple should give their best to maintain their marriage as long as they can because divorce has a negative effect on children, as said in Islam that "divorce is allowed (lawful), but Allah hates it".

But the fact is, not all household's life runs lasting, smooth, or ends happily. The decision to divorce became the last resort that must be taken for married couples through court decisions both in the District Court (nonIslamic couples) and the Religious Courts (Islamic couples). The Religious Court is an institution that has the authority to decide a case that covers marriage, inheritance, trust, grants, infaq, shadaqah, and sharia economics. However, in the Province of Aceh there is a special institution that has the authority in this regard, i.e the Shari'a Court which is is based on Law No. 18 of 2001 concerning Special Autonomy.

Sharia Court of Aceh is part of the Religious Court which found at Muharram 1, $1424 \mathrm{H} /$ March 4, 2003, M according to Act No. 18 of 2001, Presidential Decree No. 11 of 2003 and The Qanun of Aceh No. 10 of 2002 (Mahkamah Syar'iyah Aceh).

Based on the last five years (2012 2017) data of Sharia Court of Aceh, divorce cases tend to increase as shown in chart 1 .

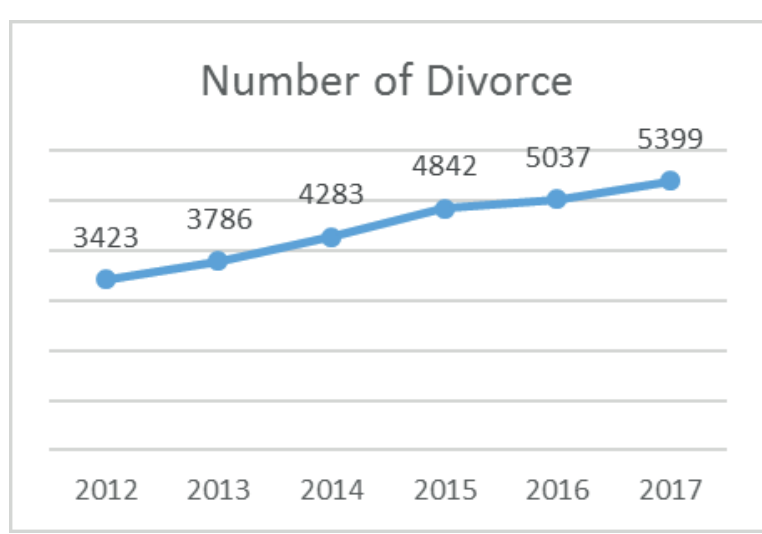

Chart 1. Data of Divorce in Aceh in $2012-2017$

Based on Chart 1, the number of divorce cases in Aceh in 2012 was 3.423 cases. It rose up to 11 percent in 2013 (3.786 cases). Every year the divorce cases increase 4 to 13 percent, which at the end of 2017, it reached 5.399 cases. North Aceh, Bireun, and Central 
Aceh become the regions with the highest cases of divorce, while the lowest ones are Sabang and Aceh Jaya.

However, it is interesting that there are a number of divorce cases filed by the wife. This is consistent with data from the Aceh syar'iah court stating that the number of divorces filed by the wife reached 3,679 cases. It was higher than the number of divorces requested by the husband of 1,358 cases in 2016 which increased to 3,981 cases in 2017 that is higher than the number of divorces requested by the husband of 1,508 cases.

The tendency of an increase in divorce cases filed by the wife indicates a change in social values and an increasing number of women who aware of their rights and obligations. According to Widyastuti (2009: 395), women as wives do not remain silent and do not want to be treated arbitrarily by men so that they use their rights by filing for divorce to court.

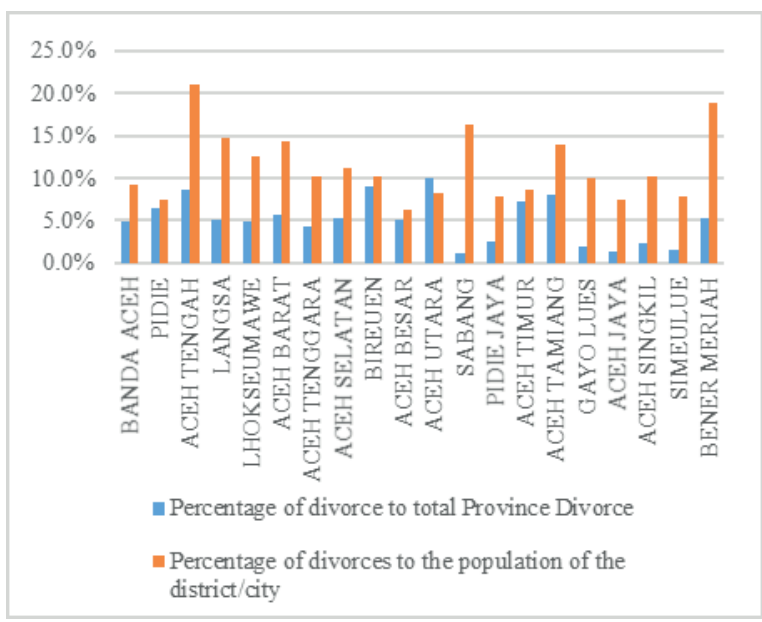

Chart 2.Percentage of Divorce and Population of Aceh in 2015

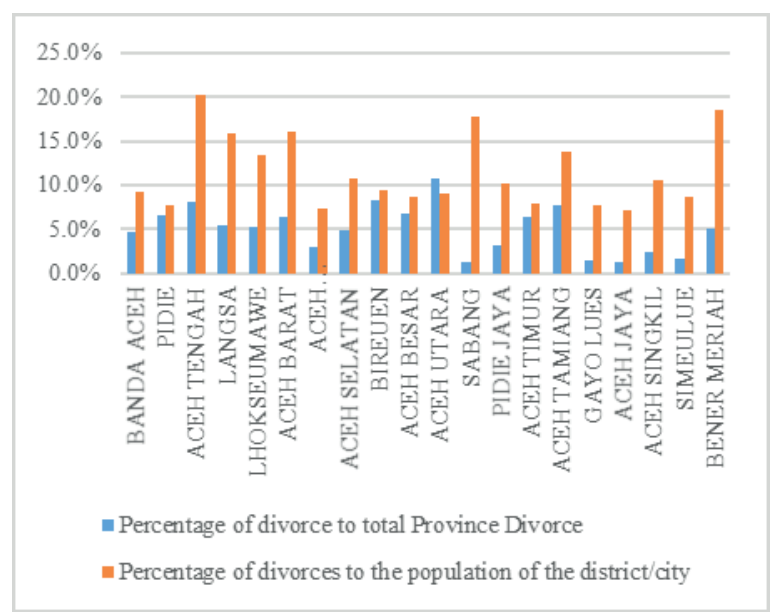

Chart 3. Percentage of Divorce and Population of Aceh in 2016

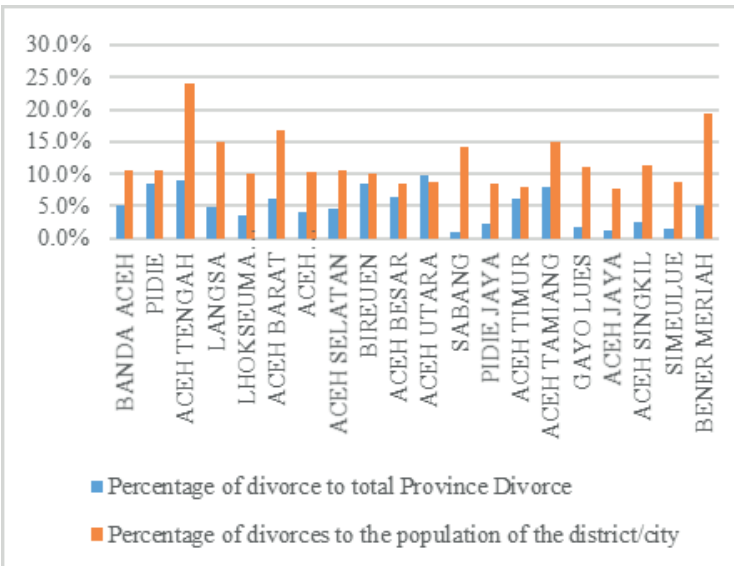

Chart 4. Percentage of Divorce and Population of Aceh in 2017

However, the interesting thing is the phenomenon of divorce filed by the wife recorded at Sharia Court of Aceh that reached 3.679 cases, which are higher than divorce filed by the husband ( 1.358 cases) in 2016 and become 3.981 cases compared to 1.508 cases in 2017.

The phenomenon of divorce indicates the transition of social values and more women are aware of their rights and obligations. According to Widyastuti (2009: 395), a woman as a wife doesn't remain silent and doesn't want to be mistreated by a man, so that they use their rights by filing for divorce in court. This condition occurred due to the increasing knowledge of women, especially related to the issue of rights and obligations in the household. In addition, the existence of the legal protection for women in defending their rights is also contributed to the increasing awareness of women's rights.

\section{Divorce Factors Analysis}

As described above, divorce is the breaking up of a marriage. Since the enactment of Act No. 1 of 1974 concerning marriage, Government Regulation No. 9 of 1975 concerning the implementation of the marriage law, and Act No. 3 of 2006 concerning the Religious Courts amended from Act No. 7 of 1989 concerning the Religious Courts giving an understanding to the public about the legal divorce process.

As the enactment of the above laws, it is expected that there will be no divorce outside of the court or illegal divorce.

The factors of reasons for a wife filing for divorce or a husband submitting 
for divorce are used as basic judgment to examine and consider in accordance with Islamic regulation. Many factors influence the breakup of marriage until the divorce occurs which can be caused by internal factors of the family or external factors such as the third party.

According to data from Sharia Court of Aceh, factors that trigger the divorce in 2017 are recur of friction, being irresponsible, economic problems, and domestic violence which is shown in Table 1.

Table 1

\section{Factors Causing Divorce} in Aceh in 2017

\begin{tabular}{llr}
\hline No & Factors of Divorce & $\begin{array}{l}\text { Number of } \\
\text { Cases }\end{array}$ \\
\hline 1 & Adultery & 2 \\
2 & Disability & 34 \\
3 & Apostate & 1 \\
4 & Forced Marriage & 36 \\
5 & Drunk & 33 \\
6 & Gambling & 44 \\
7 & Sentenced to Prison & 19 \\
8 & Domestic Violence & 121 \\
9 & Irresponsible & 732 \\
10 & Recur of Friction & 3663 \\
11 & Economic & 497 \\
12 & Polygamy & 16 \\
13 & Others & 114 \\
14 & Total & 5312 \\
\hline
\end{tabular}

\section{Analysis of Socio Economic Factors in Divorce}

\section{Level of Education}

Education is one of the important things in human life because through education the human could create civilized societies that live in happiness and prosperity. The higher the goals or prosperity desired, the higher the level of education needed. Based on a simple understanding, education can be interpreted as a human effort to grow and develop their potential both physical and spiritual according to values that exist in society and culture (Ihsan, 2008: 1-2).

People's mindsets will also be formed through education which makes education crucial. A well-developed mindset will make someone think critically on something from various points of view so that they are able to decide everything carefully without being easily affected by negative things. Therefore, someone who has a higher level of education tends to be more open-minded than those who are completely uneducated. Their mindset will be opened and tend to solve problems easily.

Based on data from the BPS/Statistics of Aceh Province, the divorce took place on a lower level of education which could be shown in chart 5.

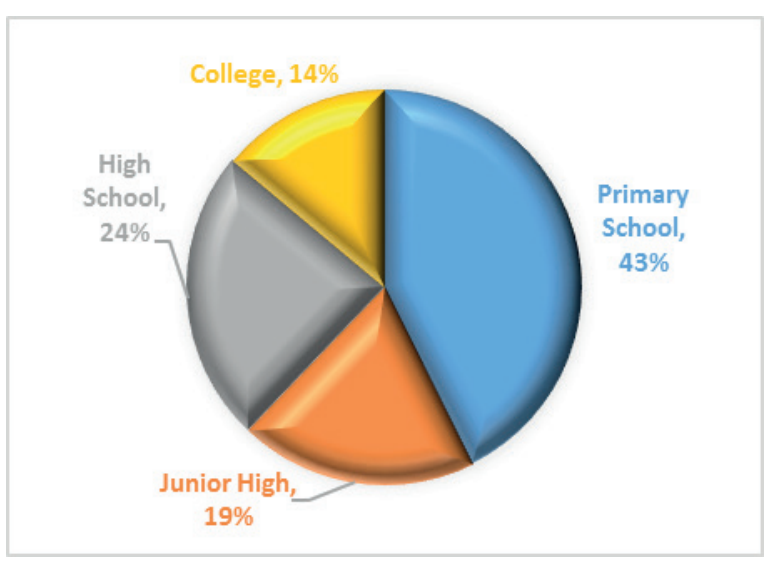

Chart 5 Education Levels

Based on chart 1.5, the highest divorce happened at the lowest level of education, which is primary school (43 percent of total divorce) in 2017.

This condition can occur because education affects the lifestyle and insight of the knowledge possessed. By having the insight or knowledge, people with higher education will become more aware by the fact that family stability is important in determining the success of a marriage and that divorce will have a negative impact on the people involved in it.

This condition has been stated in research conducted by Zuzana \& Kreidl (2018), Cavapozzi et al. (2019) and Mandemakers \& Kalmijn (2014).

\section{Age of Marriage}

Act No. 1 of 1974 article 6 set a minimum age of marriage for the man at 19 and the woman at 16 . But from the medical and psychological side, this age is considered too young to face the problems of marriage. Before reaching 21 years old, adolescents are not mentally ready for getting married because they are still in the learning process and have not matured yet. Meanwhile, from the physical side, the reproductive system of female adolescents is not fully mature yet. Getting married at an early age is having a 
risk of premature birth, maternal and infant mortality.

Besides that, getting early marriage will make the woman quit their education and forcefully becomes a housewife; meanwhile, the man does not have a job yet and depend on their parents to fulfill their needs. This situation will eventually lead to divorce. It has been stated in the research conducted by Lampard (2013), Syahnur et al. (2017), Sulaiman (2012) and Büchler \& Schlatter (2013).

Those research are in line with data from the BPS/Statistics of Aceh Province stating that household with marriages under 21 will likely be ended up with divorce $(62 \%)$ compared to those who are married at a mature age or over 21 years old (38\%) (chart 6).

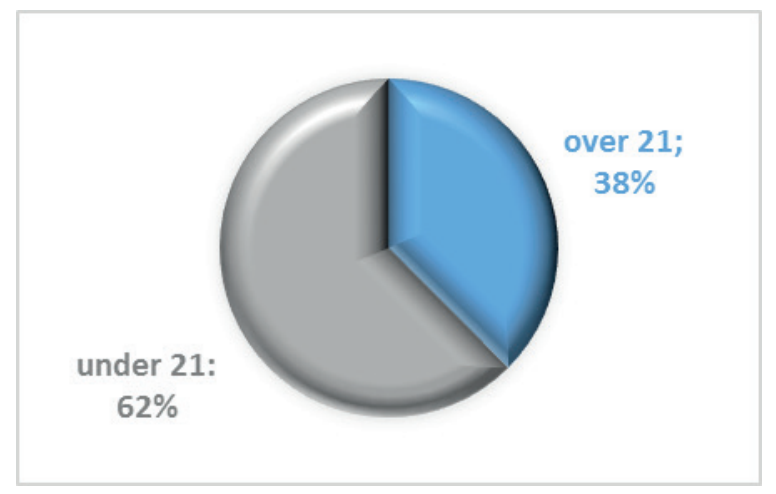

\section{Chart 6 Percentage of Age of First Marriage}

This shows that the age of first marriage is very influential in divorce. It is because the young married couples are still immature in the standard of age and personality which results in a lack of readiness to carry out their responsibilities as husband/wife. After marriage, they face many family problems, and most of them are unable to deal with it. Since they do not have much experience in dealing with problems, young couples will find it difficult to control themselves and their emotions, so that they will take the easiest way: get a divorce.

\section{Children}

People are getting married to get a descendant/children. Children make the family complete. The couple who had married for quite a long time but they have not had children yet could be one of the reasons to divorce. However, it is not always ended up with divorce since marriage is not all about having a descendant, but also to find the meaning of life, calm the tempestuous soul, and find the balancing of life. Whatever happened could be embraced smoothly even without the presence of children.

Divorce in Aceh is not always caused by having children or not since the difference of this factor is not significant, only 5 percent.

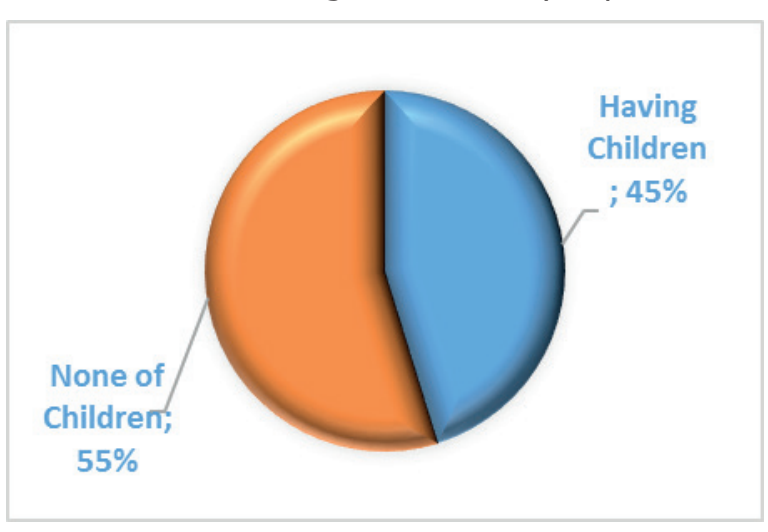
Chart 7 Percentage of Divorce of Having
Children or Not

Based on data from BPS Aceh as shown by chart 7, divorce caused by not having children is $55 \%$ compared to having children of 45 percent.

\section{Economic}

Economic is another important thing in life because this factor is a means of maintaining dan developing human civilization. Economic is pretty essential for human life so that everybody is working hard to fulfill their economic needs. The increasing economic shown the welfare of human life, which is why everyone has to work.

The importance of the economy in the family (family living) has to be considered by family members, especially for a husband who has the responsibility to take care of his wife and children. If this income is not wellpaid attention to, it often becomes a threat to the integrity of the household. Therefore, the husband and wife, especially the husband as the holder of the obligation to provide for a living, cannot assume trivial matters over this thing.

The law of sustenance is obligatory for the husband to his wife in the legal marital bond. If the husband doesn't take this seriously, it could cause another problem and will threat the harmony of the household, even may end in divorce

Based on a survey on Sharia Court of Aceh, from all factors that affect the divorce, 
economic is one of the major factors. This survey is in line with research conducted by Raz-yurovich (2011), Sandström (2011), Sakata \& Mckenzie (2011), Kabalmay (2015) dan Matondang (2014). In this case, the economic factor that caused divorce is family sustenance matter. Among them, the husband is being irresponsible and not working hard to perform his obligation in fulfilling the needs of his family. Although the husband has worked hard and responsible for his obligation, if the wife lives a glamour lifestyle, it could also cause the divorce.

Regarding Sharia Court of Aceh's data, the divorce caused by economic is 497 cases in all of Aceh Region which can be shown in chart 8.

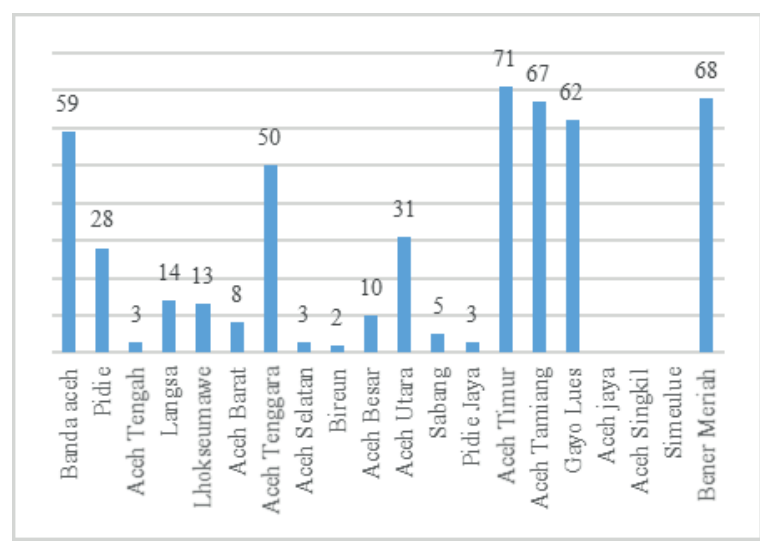

Chart 8. Number of Divorces caused by Economic Factor

However, in Aceh Province, the main cause of divorce in 2017 was not economic factors which only amounted to 497 cases, but the continuous disputes totaling 3,663 cases.

Economic factors as a reason for acts of divorce actually appear after the emergence of other factors or even as an amplifier of reasons for deviant actions. The factors causing divorce tend to be sociological factors of the community. Economic reasons often just become the amplifier of divorce decision making and make it easier and faster in the trial process in court.

\section{Recur of Friction}

Law No. 1 of 1974 concerning Marriage had not regulated the factors or reasons for divorce. This factor later on described in Government Regulation No. 9 of 1975 on the implementation of Law No. 1 of 1974 concerning Marriage. Article 19 of that Government Regulation mentioned 6 (six) reasons for divorce, one of them is "Recur of Friction and quarrel among husband and wife, and there is no hope of living in harmony again in the household".

Living with another person without legal permission or another thing beyond the ability is one factor that causes divorce according to Islamic Law as emphasized by Sudarsono (1994) who arranged about nusyuz for the husband or wife as the reason for divorce law. For example nusyuz of the husband is not fulfilling conjugal needs of the wife, while zusruz of the wife is living in or leaving the house without husband permission or other things, husband and wife are leaving their obligation as a couple that leads to estrangement among them. It is in line with research by Härkönen (2013), Jalovaara (2003, 2010), Harahap (2015), Marinescu (2016), Sakata \& Mckenzie (2009) dan Karlina et al. (2017).

Interference of both parents is another factor that causes friction in their children's household that makes their children depressed. Parents' interference, one way or another, is not creating harmony in their children's household. This is in accordance with the research of Apostolou et al. (2016).

Chart 9 shows data form Sharia Court of Aceh stating that 3.663 cases of divorce caused by the recur of friction and become the highest factor in 2017.

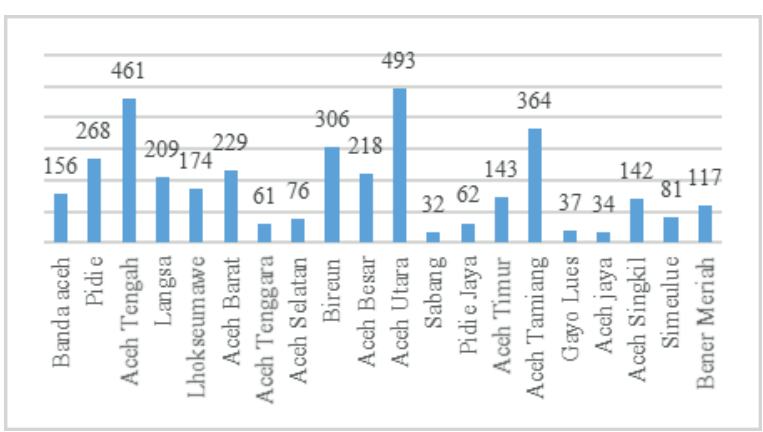

\section{Chart 9. Number of Divorce Caused by Recurring of Friction}

However, divorce cases due to ongoing disputes that often occur in Aceh Province cannot be drawn conclusions of the background of the dispute, whether it is because of the economy or a third person or other things. It is due to the researchers' limited data and time for the data collection itself.

\section{Domestic Violence}

Another factor that causes divorce is 
domestic violence. Article 1 of Act No. 23 of 2004 about the eradication of Domestic Violence state that domestic violence is every action against someone, especially for the women, that resulting in misery and suffering physically, sexually, psychologically, and or the negligence of the household including threats of coercion or deprivation of liberty against the law in the family. Thus, these acts of a member of the families could cause a divorce, which in accordance with the research conducted by García (2014) and Prianto et al. (2013).

Divorce caused by domestic violence in 2017 was recorded in 121 cases. Aceh Timur (East Aceh) Regency became the most cases of divorce in Aceh which almost had 46 cases compared to Banda Aceh that only had 19 cases. Nevertheless, not all the city or regency have divorce cases such as Langsa, West Aceh, North Aceh, Aceh Tamiang, Gayo Lues, Aceh Singkil dan Simeulue (chart 10).

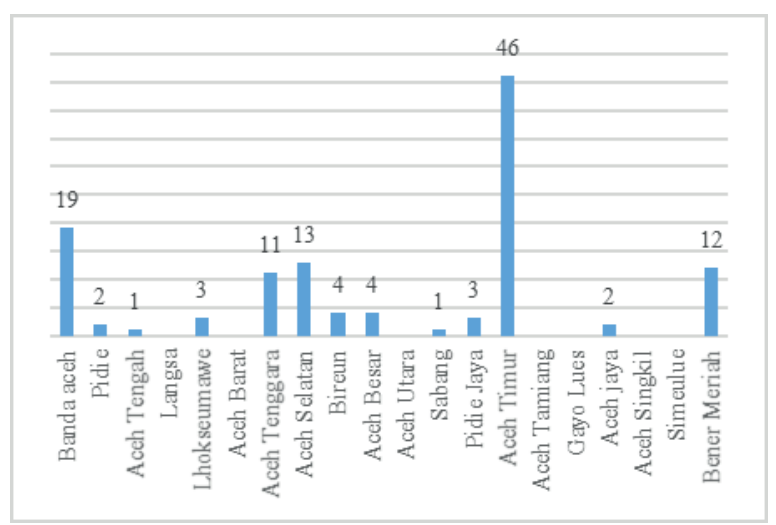

Chart 10. Number of Divorce Caused by Domestic Violence

\section{Conclusions}

Divorce rates in Aceh Province continue to increase in recent years. Therefore, this paper examines the factors behind the increasing divorce in Aceh Province. Data for the analysis of this study were drawn from two sources. First, the Aceh Syar'iah Court in the form of data on the results of a court decision on divorce in 2017. Second, the Statistics of Aceh Province in the form of data on the socioeconomic survey (SUSENAS) in 2017. The analysis was conducted on the decisions of the Court and the Central Statistics Agency to estimate the possibility of the successful divorce suit. It was found that in Aceh Province, the most influencing factor for an individual to divorce was a matter of continuous disputes and the leaving of one party. While economic factors, education levels, child factors, marital age factors, and domestic violence are not the main factors that determine an individual's decision to divorce.

Individual-level of education tends to significantly affect divorce cases. A person who has a low educational level (elementary school graduated or equivalent) have greater opportunities for divorce compared to a person with a higher level of education such as Senior High School and equivalent. However, these conditions do not apply in urban areas such as Banda Aceh and Lhokseumawe since those areas have a lot of people from higher education level that got divorced. Children variable has affected the divorce, but according to data of BPS/ Statistics of Aceh Province, the influence is not too significant both for having children or not having them. The result of processed data showed that the age of first marriage has a greater affected on divorce especially the age of first marriage under 21 years old.

\section{References}

Act No. 3 of 2006 concerning the Religious Courts amended from Act No. 7 of 1989 concerning the Religious.

Apostolou, M. et al. (2016). Parent-offspring conflict over mating: The case of divorce, 99, 286-294.

Article 1 of Law Act No. 23 of 2004 about the eradication of Domestic Violence.

Article 38 of Law Act No. 1 of 1974 on marriage. Surabaya: Tinta Mas

Badan Pusat Statistik Provinsi Aceh, (2011). Pedoman Pendataan Survei Sosial Ekonomi Nasional Tahun 2017. Banda Aceh: Badan Pusat Statistik

Büchler, A., \& Schlatter, C. (2013). Marriage Age in Islamic and Contemporary Muslim Family Laws A Comparative Survey by Andrea Büchler and Christina Schlatter, 1.

Cavapozzi, D., Fiore, S., \& Pasini, G. (2019). Divorce and well-being. Disentangling the role of stress and socioeconomic status. The Journal of the Economics of Ageing, 100-212.

García, A. M. (2014). Divorce and abuse in 16th, 17th and 18th century Spain. Procedia - Social and Behavioral Sciences, $161,184-194$.

Harahap, T. H. (2015). Fenomena Kasus Cerai Gugat (Studi Kasus di Mahkamah Syar'iyah Tapaktuan), 1 (2), 39-49.

Ihsan, F. (2008). Dasar-Dasar Kependidikan. Bandung: Rineka Cipta Press 
Jalovaara, M. (2003). The joint effects of marriage partners' socioeconomic positions on the risk of divorce. Demography, 40 (1), 67-81.

Jalovaara, M. (2010). Socio-economic status and divorce in first marriages in Finland 1991-93.

Härkönen, J. (2013). Divorce : Trends, Patterns, Causes, Consequences.

Kabalmay, H. A. (2015). Kebutuhan Ekonomi Dan Kaitannya Dengan Perceraian (Studi Atas Cerai Gugat Di Pengadilan Agama Ambon), $x i, 47-67$.

Karlina, E., Arif, M., \& Sodikin. (2017). Pengaruh bekerja di luar negeri terhadap tingkat ekonomi dan perceraian. Social Science Education Journal, 4(1), 54-60.

Lampard, R. (2013). Age at marriage and the risk of divorce in England and Wales, 29 (July), 167-202.

Mahkamah Syar'iyah Aceh, (2017). Data perceraian kabupaten/kota Provinsi Aceh.

Mandemakers, J. J., \& Kalmijn, M. (2014). Do mother's and father's education condition the impact of parental divorce on child well-being?. 44, 187-199.

Marinescu, I. (2016). Divorce: what does learning have to do with it? Labour Economics.

Matondang, A. (2014). Faktor-faktor yang Mengakibatkan Perceraian dalam Perkawinan. Jurnal Ilmu Pemerintahan dan Sosial Politik, 2 (2), 141-150.

Prianto, B., Wulandari, N. W., \& Rahmawati, A. (2013). Rendahnya Komitmen Dalam Perkawinan Sebagai Sebab Perceraian. Jurnal Komunitas, 5 (62), 208-218.

Rais, I. (2014). Tingginya Angka Cerai Gugat (Khulu') Di Indonesia; Analisis Kritis Terhadap Penyebab Dan Alternatif Solusi Mengatasinya, 191-204.

Raz-yurovich, L. (2011). Economic Determinants of Divorce among DualEarner Couples : Jews in Israel, 49 (0).

Rodgers, Boyce, K. \& Rose, Hillary A. (2002). Risk and Resiliency Factors Among Adolescent Who Experience Marital
Transition. Journal of Marriage and Family. Vol. 64,1024-1037.

Sakata, K., \& Mckenzie, C. R. (2009). The impact of divorce precedents on the Japanese divorce rate. Mathematics and Computers in Simulation, 79, 2917-2926.

Sakata, K., \& Mckenzie, C. R. (2011). Social security and divorce in Japan. Mathematics and Computers in Simulation, 81(7), 1507-1517.

Sandström, G. (2011). Socio-economic determinants of divorce in early twentiethcentury Sweden. History of the Family, 16 (3), 292-307.

Soekanto, S. (2007). Sosiologi suatu Pengantar. Jakarta: PT Raja Grafindo Persada.

Subekti (1985). Pokok-Pokok Hukum Perdata, Jakarta: Intermasa.

Sudarsono (1994) Hukum Perkawinan Nasional, Jakarta: PT. Rinekacipta.

Sugiyono. (2011). Metode Penelitian Kuantitatif, Kualitatif dan $R \& D$. Bandung: Afabeta

Sulaiman. (2012). Dominasi Tradisi Dalam Perkawinan Di BawahUmur, 19, 15-26.

Syahnur, S., Ilham, R., \& Munawar, E. (2017). The Correlation of Information and Counseling Sources for Students with Maturing Marriage Age (MMA), Indonesia, 4 (3).

Tamborini, C. R., Couch, K. A., \& Reznik, G. L. (2015). Long-term impact of divorce on women 's earnings across multiple divorce windows: A life course perspective. Advances in Life Course Research.

Thalib, A. \& Lestari, M. (2017). Tingginya Tingkat Gugat Cerai Di Pengadilan Agama Pekanbaru, Xvii(1).

Widyastuti, R. (2009). Peran Hukum dalam Memberikan Perlindungan terhadap Perempuan dari Tindak Kekerasan di Era Globalisasi, Jurnal Mimbar Hukum, FH UGM, Yogyakarta. Hal. 395.

Zuzana, Ž. \& Kreidl, M. (2018). Grandparenting after divorce: Variations across countries, 38 (January 2017), 61-71. 